\title{
Synovial Chondromatosis of Dorsal Spine: Case Report of Rare Pathological Entity and Review
}

\author{
Raviraj S. Ghorpade, Yadhu K. Lokanath \\ Department of Neurosurgery, J N Medical College, KLE'S Dr Prabhakar Kore Hospital \& Medical Research Centre, Belagavi, India
}

Synovial chondromatosis is an uncommon benign condition of metaplastic and focal formation of cartilage in the intimal layer of synovial membrane of joints with extremely low risk of malignant potential. Disease process is typically monoarticular predominantly involving large joints and spinal involvement being a very rare event. We report 31-year-old male patient who presented with history of low backache, left lower limb pain, difficulty in micturition since 8 months and difficulty in walking since 2 months .Magnetic resonance imaging of spine revealed D10-11 extradural lesion arising from left facet joint. Lesion was excised completely by posterior approach with resolution of symptoms. Literature reveals fourteen cases of spinal variant of synovial chondromatosis which has been published and this report represents the fifteenth case.

Key Words: Synovial chondromatosis $\cdot$ Dorsal spine $\cdot$ Facet joint

\section{INTRODUCTION}

Synovial chondromatosis (SC) is a rare monoarticular pathological entity of unknown origin diagnosed on pathological confirmation characterised by synovial proliferation and metaplasia, resulting in multiple intra-articular cartilaginous loose bodies in the synovium of joint producing mechanical symptoms. The disease process involves calcification or ossification of cartilaginous nodules in the joint and extrude to the loose bodies in the joint space or extra-articular extension into soft tissue $^{1-4)}$. Compression on bone and nerves is caused by calcified or ossified bodies and can cause bone erosion or pain on movement or even at rest ${ }^{5,6,9,11,12)}$. Including this current description, there are fifteen cases of spinal SC reported in medical literature ${ }^{15,17)}$ (Table 1).

\section{CASE REPORT}

Thirty-one-year-old male patient presented with history of low backache with left lower limb pain, difficulty in micturition since 8 months and difficulty in walking due to tightness of lower limbs since 2 months. Left lower limb pain intensity recor-

- Received: February 8, 2016 • Revised: October 31, 2016

- Accepted: November 17, 2016

Corresponding Author: Raviraj S. Ghorpade

Department of Neurosurgery, J N Medical College, KLE'S Dr Prabhakar Kore Hospital \& Medical Research Centre, Nehru Nagar, Belagavi,

Karnataka 590010, India

Tel: +91-8312551924, Fax: +91-8312475375

E-mail: neuroraviraj@rediffmail.com

$\otimes$ This is an open access article distributed under the terms of the Creative Commons Attribution Non-Commercial License (http://creativecommons.org/licenses/by-nc/4.0/) which permits unrestricted non-commercial use, distribution, and reproduction in any medium, provided the original work is properly cited. ded on a visual analogue scale was of seven points. Neurological examination revealed, muscle strength of grade II in left lower limb and grade III in right lower limb according to British Medical Research Council grading. Patient had grade 3 spasticity (modified Ashworth scale), exaggerated deep tendon reflexes in left lower limb with normal sensory component and extensor plantar reflexes in both lower limbs. Haematological work up was normal. Magnetic resonance imaging (MRI) of spine revealed an extradural lesion at D10-D11 arising from
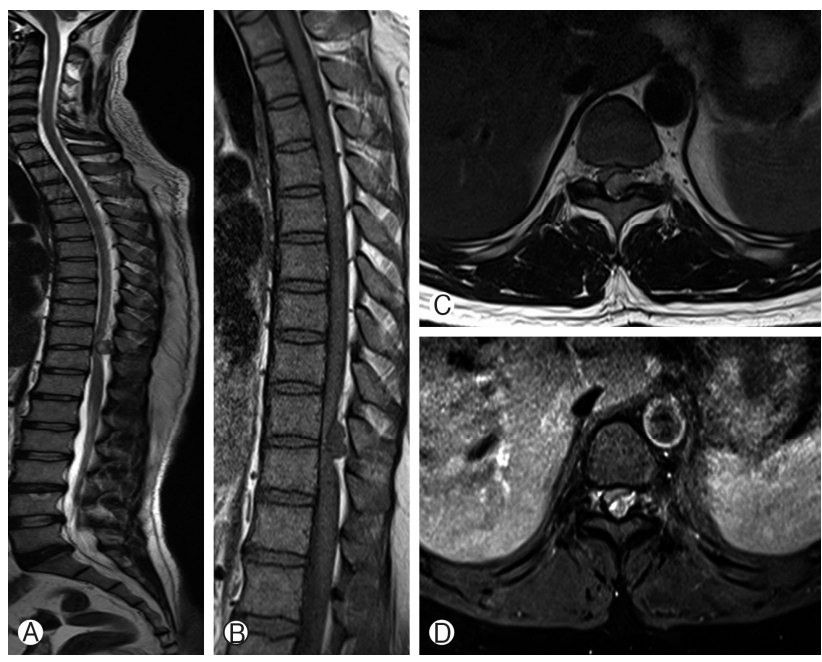

Fig. 1. Magnetic resonance imaging of spine. (A) Sagittal T2weighted image shows extradural lesion opposite to D10-11 intervertebral disc space with attachment towards ligamentum flavum. (B) Sagittal T1 contrast weighted imaging showing minimal peripheral contrast enhancement. (C) Axial T2-weighted image shows iso- to hypointense lesion compressing the cord extradurally arising from left synovial joint. 
left facet joint, lesion was hypo to isointense on T1 and T2 MRI sequence with conus compression; on gadolinium injection minimum peripheral enhancement was seen (Fig. 1).

Patient was planned for elective surgery and underwent dorsal hemilaminectomy of D10, D11, and D12 with removal of facet joints at involved level followed by total excision of firm to hard tumour. Histopathology revealed fragments of bone, disc and cartilage with a lesion composed of chondriod nodules having chondrocytes in clusters. Chondrocytes showed hyperchromatic nuclei and binucleation with one fragment of tissue showing vascularised lining resembling synovium. No mitotic activity and necrosis was suggesting typical features of SC (Fig. 2). At follow-up of 3 weeks, patient was pain free, reduction of spasticity to grade 1 with restoration of normal daily activities and better bladder control was present.

\section{DISCUSSION}

SC is a benign metaplastic pathological entity rather than a neoplastic one, in which nodules are formed from aggregates of chondrocytes in the synovium which is the cause for patient's mechanical symptoms ${ }^{17}$. SC of the spine is an extremely

Table 1. Locations and presenting symptoms of 15 reported cases of vertebral Synovial chondromatosis

\begin{tabular}{|c|c|c|c|c|c|}
\hline No. & Author & Age/sex & Presenting symptom & Location & Treatment \\
\hline 1 & $\begin{array}{l}\text { Coscia et al. } \\
1986\end{array}$ & $31 / \mathrm{F}$ & $\begin{array}{l}\text { Back pain radiating to } \\
\text { breast }\end{array}$ & Rt T5-6 facet & T5-6 facetectomy and laminectomy \\
\hline 2 & $\begin{array}{l}\text { Milchgrub et al. } \\
1992\end{array}$ & $32 / \mathrm{M}$ & $\begin{array}{l}\text { Painless slowly-growing } \\
\text { neck mass }\end{array}$ & Lt 1st costotransverse & $\begin{array}{l}\text { En bloc resection of segment of } 1 \text { st } 3 \text { left } \\
\text { ribs and contiguous tissue }\end{array}$ \\
\hline 3 & $\begin{array}{l}\text { Burrafato et al. } \\
1998\end{array}$ & $31 / \mathrm{F}$ & Painful lumbar mass & Rt L4-5 facet & Resection of mass and L4-5 facetectomy \\
\hline 4 & $\begin{array}{l}\text { Birchall et al. } \\
1999\end{array}$ & $60 / \mathrm{M}$ & Leg weakness & Lt T4-5 facet & Resection of mass and T3-5 laminectomy \\
\hline 5 & $\begin{array}{l}\text { Kyriakos et al. } \\
2000\end{array}$ & 39/M & Neck, shoulder, arm pain & Lt C3-4 facet & Lt C3-4 facetectomy and hemilaminectomy \\
\hline 6 & $\begin{array}{l}\text { Greenlee et al. } \\
2002\end{array}$ & $48 / \mathrm{M}$ & Shoulder, arm pain & Lt C4-5 facet & Complete resection and anterior approach \\
\hline 7 & $\begin{array}{l}\text { Chiba et al. } \\
2003\end{array}$ & $52 / \mathrm{F}$ & Shoulder pain & Rt C7-T1 facet & C7-T1 facetectomy and laminectomy \\
\hline 8 & $\begin{array}{l}\text { Gallia et al. } \\
2004\end{array}$ & $46 / M$ & Neck pain & Lt C1-2 facet & $\begin{array}{l}\text { 1st: Left C1-C2 hemilaminectomy, total } \\
\text { faectectomy, occipitocervical fusion } \\
\text { 2nd: Lttransmandibular, circumglossal } \\
\text { approach }\end{array}$ \\
\hline 9 & $\begin{array}{l}\text { Gallia et al. } \\
2004\end{array}$ & $22 / \mathrm{F}$ & Neck pain & Lt C4-5 facet & $\begin{array}{l}\mathrm{C} 2-5 \text { facetectomy and laminectomy, } \mathrm{C} 2-5 \\
\text { fusion }\end{array}$ \\
\hline 10 & $\begin{array}{l}\text { Abdelwahab et al. } \\
2008\end{array}$ & $41 / \mathrm{M}$ & Buttock pain & Lt L4-5 facet & $\begin{array}{l}\text { L5 hemilaminectomy and complete } \\
\text { resection }\end{array}$ \\
\hline 11 & $\begin{array}{l}\text { Kim et al. } \\
2009\end{array}$ & $24 / \mathrm{F}$ & $\begin{array}{l}\text { Low back pain, radiating } \\
\text { leg pain }\end{array}$ & Rt L5-S1 facet & $\begin{array}{l}\text { Resection of mass and Interlaminar } \\
\text { approach }\end{array}$ \\
\hline 12 & $\begin{array}{l}\text { Moody et al. } \\
2010\end{array}$ & $44 / M$ & Neck, shoulder, arm pain & Rt C1-2 facet & $\begin{array}{l}\text { En bloc resection of mass } \\
\text { Right C1-2 facetectomy and laminectomy, } \\
\text { C1 to } 4 \text { fusion }\end{array}$ \\
\hline 13 & $\begin{array}{l}\text { Han et al. } \\
2010\end{array}$ & $21 / M$ & Shoulder pain & Rt C6-7 facet & $\begin{array}{l}\text { 1st: Right C6-7 facetectomy, C6 } \\
\text { hemilaminectomy } \\
\text { 2nd: Another right } \text { C6 }^{-7} \text { facetectomy and } \\
\text { complete resection }\end{array}$ \\
\hline 14 & $\begin{array}{l}\text { Medhkour et al. } \\
2015\end{array}$ & $58 / \mathrm{F}$ & $\begin{array}{l}\text { Lower back pain with } \\
\text { unilateral radiation } \\
\text { down her left leg }\end{array}$ & L4-L5 & Posterior approach, laminectomy \\
\hline 15 & Present one & $31 / \mathrm{M}$ & $\begin{array}{l}\text { Low backache, difficulty } \\
\text { in micturation, left lower } \\
\text { limb pain }\end{array}$ & D10-11 & $\begin{array}{l}\text { Dorsal hemilaminectomy of D10, D11, and } \\
\text { D12 with removal of facet joints at } \\
\text { involved level followed by total excision } \\
\text { of bony tumour }\end{array}$ \\
\hline
\end{tabular}



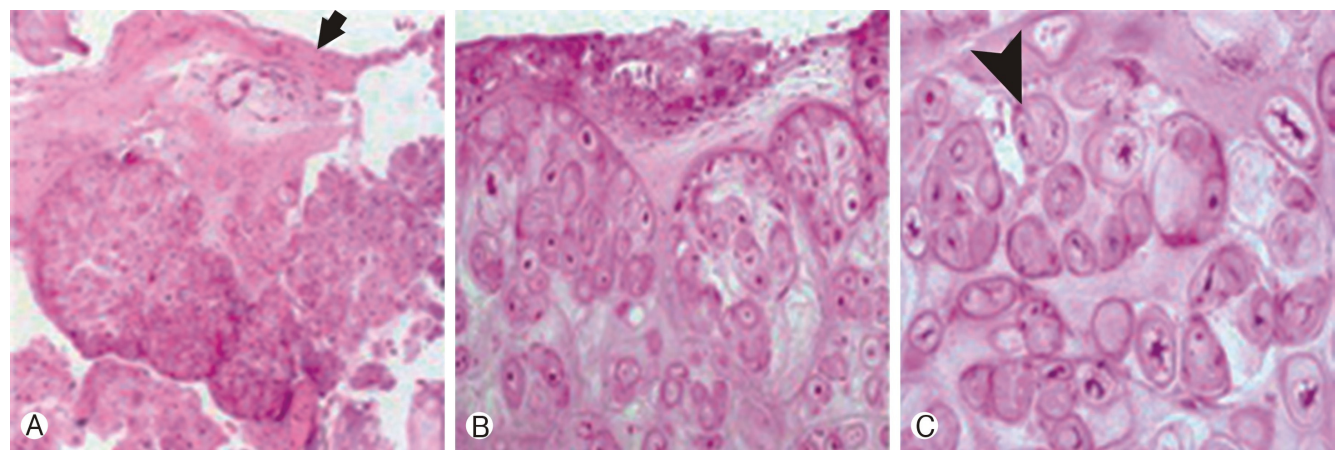

Fig. 2. (A) Photomicrographs showing a lesion composed of nodules of hyaline cartilage with overlying flattened synovial lining (arrow) (H\&E, $\times 50)$. (B) The chondrocytes are clustered and exhibit nuclear atypia with binucleation and hyperchromatic nuclei $(\mathrm{H} \& \mathrm{E}, \times 100)$. (C) Histological features are characteristic of synovial chondromatosis (arrowhead) $(\mathrm{H} \& \mathrm{E}, \times 200)$.

rare disease which has been reported only in series of case reports. Among those cases, cervical spine was the most frequent site of involvement till $2010^{18)}$.

SC can be divided into primary and secondary forms. Primary SC represents a benign idiopathic neoplastic disease process and secondary SC is associated with joint abnormalities like arthritic or mechanical conditions that can lead to intra-articular chondral bodies ${ }^{10}$. The median age at the time of presentation of vertebral SC is 39 years (range, 21 to 60 years), and the male to female ratio is approximately $1: 1$. Pain was the most common presenting symptom in 9 patients and other symptoms included a growing mass, weakness and paraesthesia $^{15}$. Definitive preoperative diagnosis of SC is exceedingly difficult and challenging due to the nondescript clinical presentation and vague characteristic profile of imaging $1^{4,9,18}$. Clustered chondrocytes show varying nuclear polymorphism, binucleate cells, increased mitotic activity, and prominent cellularity are seen microscopically ${ }^{7,16}$. Thus preoperatively it is diagnosis of exclusion and definitive confirmative diagnosis is often made postoperatively after analysing microscopic features. Characteristic typically calcified or osseous bodies are seen on plain radiography, however calcification may not be seen in $5 \%$ to $30 \%$ of cases because of the lack of matrix mineralization, those had appeared as water-dense foci. Computed tomography scan typically reveals a soft-tissue mass with multiple calcifications. MRI reveals nodules are seen using an intermediate to isointense signal on T1 sequences, high signal intensities on $\mathrm{T} 2$ sequences and enhancement after gadolinium administration ${ }^{1,9,13)}$. Due to malignant transformation risk with recurrence of approximately $6 \%$ to $17 \%$, inferred from extravertebral SC, recommended treatment is surgery which includes removal of the loose body or mass and the complete synovectomy of the affected joints which is highly effective in alleviating the symptoms. Although the recurrence rate is very low in vertebral SC, it is thought that recurrence is secondary to incomplete removal of synovial lining and no agreed treatment guideline is available. Arthrodesis has been reported to be a successful as a salvage treatment option for recurrent SC and in case instability is suspected ${ }^{7,8,13,14,16}$.

\section{CONCLUSION}

To summarize it is a benign uncommon pathology entity without any definitive preoperative diagnostic features. Surgery is the definitive treatment and confirmation by histology which should be considered as gold standard. Complete resection prevents recurrence.

\section{CONFLICT OF INTEREST}

No potential conflict of interest relevant to this article was reported.

\section{REFERENCES}

1. Abdelwahab IF, Contractor D, Bianchi S, Hermann G, Hoch B: Synovial chondromatosis of the lumbar spine with compressive myelopathy: a case report with review of the literature. Skeletal Radiol 37:863-867, 2008

2. Birchall D, Khangure MS, Spagnolo DV: Vertebral synovial osteochondromatosis with compressive myelopathy. Spine (Phila Pa 1976) 24:921-923, 1999

3. Burrafato V, Campanacci DA, Franchi A, Capanna R: Synovial chondromatosis in a lumbar apophyseal joint. Skeletal Radiol 27:385-387, 1998

4. Chiba S, Koge N, Oda M, Yamauchi R, Imai T, Matsumoto H, et al: Synovial chondromatosis presenting with cervical radiculopathy: a case report. Spine (Phila Pa 1976) 28:E396-400, 2003

5. Choi JK, Ryu KS, Lee H, Lee K, Park CK: Correlation between th e symptomatic lumbar synovial cyst and facet degeneration: retrospective study of 13 surgical cases. Korean J Spine 8:113117, 2011

6. Coscia MF, Edmonson AS, Pitcock JA: Paravertebral synovial osteochondromatosis. A case report. Spine (Phila Pa 1976) 11: 82-87, 1986

7. Crotty JM, Monu JU, Pope TL Jr: Synovial osteochondromato- 
sis. Radiol Clin North Am 34:327-342, xi, 1996

8. Fandburg-Smith J: Cartilage and Bone Forming Tumors and Tumor-Like Lesions. in Miettinen M(ed). Diagnostic Soft Tissue Pathology. Newyork: Churchill Livingstone, Chapter 17, pp405406.410-411, 2003

9. Gallia GL, Weiss N, Campbell JN, McCarthy EF, Tufaro AP, Gokaslan ZL: Vertebral synovial chondromatosis. Report of two cases and review of the literature. J Neurosurg Spine 1:211-218, 2004

10. Goldblum JR, Weiss SW: Cartilaginous Soft Tissue Tumors. in Weiss SW, Goldblum JR, Enzinger FM (eds). Soft Tissue Tumors, ed 5. Philadelphia. Mosby Elsevier, pp1017-1023, 2008

11. Greenlee JD, Ghodsi A, Baumbach GL, VanGilder JC: Synovial chondromatosis of the cervical spine. Case illustration. J Neurosurg 97(1 Suppl):150, 2002

12. Han JS, Lee SH, Kim ES, Eoh W: Regrowing synovial chondromatosis in a cervical facet joint with radiculopathy. Korean J Spine 9:253-256, 2012
13. Hermann G, Abdelwahab IF, Klein M, Kenan S, Lewis M: Synovial chondromatosis. Skeletal Radiol 24:298-300, 1995

14. Kenan S, Abdelwahab IF, Klein MJ, Lewis MM: Case report 817: Synovial chondrosarcoma secondary to synovial chondromatosis. Skeletal Radiol 22:623-626, 1993

15. Medhkour A, Entezami P, Gatto-Weis C: Acute left-sided foot drop attributed to recurrent synovial chondromatosis of the lumbar spine. J Spine 4:230, 2015

16. Miller MV, King A, Mertens F: Cartilage Tumours. in Fletcher K, Unni K, Mertens F (eds). Pathology and Genetics of Tumours of Soft Tissue and Bone, Lyon: IARC Press, Chapter 10, pp246, 2002

17. Moody P, Bui MM, Vrionis F, Setzer M, Rojiani AM: Synovial chondromatosis of spine: case report and review of the literature. Ann Clin Lab Sci 40:71-74, 2010

18. Murphey MD, Vidal JA, Fanburg-Smith JC, Gajewski DA: Imaging of synovial chondromatosis with radiologic-pathologic correlation. Radiographics 27:1465-1488, 2007 